\title{
HUBUNGAN CITRA MERK BUS (MGI) DENGAN KEPUASAN KONSUMEN PADA TRAYEK BANDUNG-SUKABUMI
}

\author{
Ulfa Chairunnisa
}

Fakultas Psikologi UIN Sunan Gunung Djati Bandung, Jl. A.H Nasution No. 105 Bandung

\begin{abstract}
Abstrak
Penelitian ini bertujuan untuk melihat hubungan antara citra merk dengan kepuasan konsumen. Design penelitian kuantitatif menggunakan metode korelasional dengan sample sebanyak 350 orang pengguna jasa Bus MGI Trayek Bandung-Sukabumi. Alat ukur yang digunakan adalah Brand Image Inventory (37 item) dan Customer Satisfaction Index (37 item). Koefisien korelasi yang diperoleh sebesar $=0.684$ berarti terdapat hubungan positif antara citra merek dengan kepuasan konsumen. Citra merek yang tinggi berhubungan dengan tingginya tingkat kepuasan konsumen dan rendahnya citra merek berhubungan dengan rendahnya kepuasan konsumen.
\end{abstract}

Kata Kunci : Citra Merk Bus, kepuasan konsumen

\section{Abstract}

This research aims to study correlation between brand image and customer satisfaction. Quantitative design using correlational method involved 350 MGI bus customer in Bandung-Sukabumi route. Instruments used are Brand Image Inventory (37 item) and Customer Satisfaction Index (37 item). Cooeficient correlation resulted is 0.684 which means that there is positive correlation between brand image and customer satisfction. High brand image correlated with high customer satisfaction while low brand image correlated with low customer satisfaction.

Keywords : Bus brand image, customer satisfaction

\section{PENDAHULUAN}

Perkembangan industri jasa transportasi saat ini sudah semakin berkembang pesat seiring dengan berbagai aktivitas masyarakat yang sangat terbantu dengan keberadaan jasa transportasi. Industri jasa transportasi saat ini juga dipandang penting karena berfungsi sebagai penopang mobilitas masyarakat. (Sukarto, dalam Purnomo 2012) terdapat lima unsur pokok transportasi, yaitu: manusia yang membutuhkan transportasi, barang yang diperlukan manusia, kendaraan sebagai sarana transportasi, jalan sebagai prasarana transportasi serta organisasi sebagai pengelola transportasi. Pada dasarnya, semua unsur tersebut saling berkaitan guna terjaminnya penumpang atau barang yang diangkut akan sampai ke tempat tujuan dalam keadaan baik seperti pada saat awal diangkut.

Penumpang atau barang yang diangkut agar dapat sampai pada tujuan, tentunya harus menggunakan alat transportasi. Alat transportasi itu sendiri dibedakan kedalam tiga jenis, yaitu darat, air dan udara. Transportasi darat seperti misalnya sepeda motor, kereta api, mobil 
penumpang, mobil barang dan mobil bus. Alat transportasi yang sering digunakan untuk skala kecil, di antaranya sepeda, becak, bajaj, bemo dan delman. Alat transportasi air (sungai, danau, laut) biasanya menggunakan kapal tongkang, perahu, rakit, dan lain-lain serta alat transportasi udara yaitu pesawat terbang. Faktanya dari ketiga jenis alat transportasi tersebut, alat transportasi darat merupakan satu-satunya yang menyebabkan terjadinya kemacetan. Namun hal tersebut dapat diantisipasi oleh adanya transportasi yang bersifat massal. Salah satu transportasi massal yang paling banyak diminati saat ini ialah bus.

Bagi masyarakat, bus merupakan alat transportasi darat yang sudah dikenal sejak dulu. Tarif bus relatif ekonomis membuat masyarakat lebih menggunakan jasa tersebut dibandingkan dengan transportasi lainnya. Oleh karena permintaan jasa transportasi bus yang semakin meningkat, persaingan dalam penyedia jasa transportasi juga bertambah ketat. Pada akhirnya, banyak penyedia jasa transportasi yang berlomba-lomba menunjukkan inovasinya untuk dapat menarik perhatian konsumen salah satunya berkaitan dengan "merek".

Menurut American Marketing Association (Kotler \& Keller, 2009:332) mendefinisikan merek sebagai:

"suatu nama, istilah, tanda, simbol, rancangan, atau kombinasi dari halhal tersebut, dan dimaksudkan untuk membedakannya dari barang-barang yang dihasilkan oleh pesaing. Para pemasar menyatakan bahwa pemberian merek adalah seni dan bagian paling penting dalam pemasaran karena merek merupakan sebuah elemen kunci yang menghubungkan perusahaan dengan konsumen, dan salah satu hasilnya adalah preferensi merek, yaitu kecenderungan konsumen untuk memilih merek tertentu."
Merek lebih dari sekedar nama dan simbol. Merek adalah janji penjual kepada konsumen untuk senantiasa konsisten memberikan keistimewaan, manfaat, dan jasa tertentu. Merek merepresentasikan persepsi dan perasaan tentang sebuah produk, termasuk penampilannya, sehingga pada akhirnya merek akan tetap berada di benak konsumen (Kotler dan Amstrong, 2008:230). Merek memiliki kekuatan dan nilai yang bervariasi di pasar, dan kecenderungan konsumen untuk memilih merek tertentu biasanya didasarkan pada citra yang dimiliki terhadap merek tersebut.

Menurut Shimp (2003:12) citra merupakan jenis asosiasi yang muncul di benak konsumen ketika mengingat sebuah merek dalam bentuk pemikiran atau persepsi tertentu yang dilanjutkan kepada suatu merek. Citra merek dibentuk berdasarkan identitas yang dikenakan kepada merek tersebut oleh produsen dan diterima sebagai persepsi oleh konsumen.

Secara umum persepsi merupakan proses saat stimuli-stimuli yang ada akan diseleksi, diorganisir, dan diinterpretasi menjadi informasi yang bermakna. Melalui pengintegrasian semua komponen yang terdapat dalam suatu merek, konsumen kemudian akan memilih merek tertentu (proses seleksi) untuk pemrosesan lebih lanjut dan mengabaikan stimuli dari merek lain. Hasil dari persepsi ini akan terbentuk citra total bagi merek. Persepsi masyarakat yang baik terhadap citra sebuah perusahaan merupakan aset yang begitu berharga dewasa ini, sebab bagi perusahaan citra merupakan keseluruhan kesan yang terbentuk di benak masyarakat tentang perusahaan. Usaha memenangkan persaingan bisnis kualitas jasa bukan lagi hal yang dapat dibanggakan, karena setiap pelaku bisnis ataupun penyedia jasa sudah pasti akan berusaha membuat kualitas yang tinggi. Citra yang baik dan konsumen yang merasakan kepuasanlah yang telah terekam dalam benak konsumen yang akan 
mendorong terjadinya rasa ketagihan untuk menggunakan jasa tersebut.

Perusahaan jasa transportasi bus di Jawa Barat relatif banyak. PT. Maya Gapura Intan (MGI) merupakan salah satu perusahaan jasa transportasi yang telah beroperasi sejak tahun 2003. MGI merupakan perusahaan milik perseorangan yang bergerak dalam bidang jasa transportasi yang didirikan secara bersama oleh Bapak H. Asep Eris Mahpud dan Bapak H. Azis Rismaya Mahpud (Maya Sari Group). MGI saat ini telah memiliki izin beroperasi ke berbagai daerah.

Internet menyediakan alat bagi para konsumen untuk menyebarkan cerita buruk dan juga cerita baik kepada orang lain di dunia (Kotler \& Keller, 2009:180). Berdasarkan data yang diperoleh, MGI telah mendapatkan citra positif di kalangan masyarakat berdasarkan hasil penelusuran melalui blog. Pada laman ini (http://andreas23.multiply.com/photos/phot o/39/5), ditemukan bahwa terdapat sejumlah masyarakat yang menyatakan bahwa MGI merupakan bus yang memiliki kemasan yang menarik melalui warna biru yang cerah. Warna adalah unsur visual yang paling menarik perhatian dan juga selalu menjadi unsur yang tidak terpisahkan dari identitas apapun di dunia bisnis bus (Hasson, 2008 : 75-76). Hasson juga mengemukakan bahwa biru merupakan lambang kedamaian serta kepemimpinan (2008 : 76-77). Hal serupa juga tampak pada blog (http://rahmanifitriana.blogspot.com/2011/ 04/talk-bout-bus.html), yang mengatakan bahwa bus MGI merupakan bus yang tidak melakukan pemberhentian di tengah perjalan untuk menambah kuantitas penumpang, sehingga para penumpang tidak perlu menunggu lama agar bis cepat sampai tujuan. Selain itu, bus MGI melarang pengamen atau pedagang asongan untuk memasuki bus yang akan berdampak pada kenyamanan dan keamanan konsumen.
Fasilitas bus MGI dirasakan nyaman, yang menjadikan citra positif lainnya adalah logo dan kemasan. Warna biru yang cerah menjadikan MGI menarik untuk dilihat. Menurut penuturan salah satu karyawan MGI bagian operasional, yaitu Bapak Ade Suherman mengatakan "warna logo itu sendiri mencirikan kesan teduh, suasana yang teduh akan membuat orang merasa nyaman".

MGI telah memiliki jumlah trayek yang cukup banyak. Trayek BandungSukabumi merupakan salah satu trayek yang paling banyak diminati dibandingkan dengan trayek lain yang ada. Faktanya, para penumpang yang melalui trayek Bandung-Sukabumi lebih banyak mengenal bus MGI dibandingkan dengan penumpang yang melalui trayek lain yang dilalui bus MGI.

Berikut data jumlah penumpang Bus MGI pada setiap trayek yang ada pada tahun 2012:

Tabel 1.1 Jumlah Penumpang Bus MGI Tahun 2012

\begin{tabular}{clc}
\hline NO & \multicolumn{1}{c}{ Trayek } & $\sum$ Penumpang \\
\hline 1 & Bandung - Sukabumi & 2.142 .555 \\
2 & Bandung - Bogor & 335.731 \\
3 & Bandung - Depok & 295.741 \\
4 & Cipularang & 243.838 \\
5 & Bandung - Cibinong & 95.900
\end{tabular}

Sumber: PT. Maya Gapura Intan (MGI)

Berdasarkan hasil observasi di lapangan tepatnya di stasiun leuwipanjang, bus MGI trayek Bandung-Sukabumi selalu diburu oleh para penumpang. Para penumpang rela menunggu hanya untuk menggunakan bus MGI trayek ini. Berikut data jumlah penumpang MGI Trayek Bandung-Sukabumi selama enam bulan terakhir pada tahun 2012. 
Tabel 1.2

Jumlah Pelanggan Bus MGI Rute BandungSukabumi

Enam Bulan Terakhir Periode 2012 - 2013

\begin{tabular}{ccc}
\hline No & Bulan & $\begin{array}{c}\text { Jumlah Pelanggan } \\
\text { (Orang) }\end{array}$ \\
\hline 1 & September & 187.966 \\
2 & Oktober & 183.803 \\
3 & November & 177.374 \\
4 & Desember & 180.651 \\
5 & Januari & 189.256 \\
6 & Februari & 155.827 \\
& Total & $\mathbf{1 . 0 7 4 . 8 7 7}$ \\
\hline
\end{tabular}

Sumber: PT. Maya Gapura Intan (MGI)

Berdasarkan data Tabel 1.2, Bus MGI trayek Bandung-Sukabumi memiliki jumlah pelanggan yang beragam selama enam terakhir. Perbedaan jumlah konsumen yang terjadi di setiap bulannya relatif stabil. Jumlah yang ada, tidak mengalami perubahan secara signifikan. Baik itu dalam hal peningkatan maupun penurunan jumlah penumpang.

Dari data Tabel 1.2, dapat dilihat bahwa jumlah penumpang terbanyak ada pada bulan Januari yakni mencapai 189.256 orang. Bulan Januari memang merupakan bulannya liburan. Di bulan ini waktu libur lebih panjang dibandingkan bulan lainnya. Terutama hari libur bagi anak-anak sekolah yang baru menyelesaikan ujian akhir. Hal tersebut merupakan momen yang tepat untuk melakukan bepergian. Selain itu, ditunjang pula dengan pergantian tahun, hampir semua orang menantikannya untuk dapat bersama dengan orang-orang terdekat. Pelanggan yang jauh rela meluangkan waktunya untuk menikmati suasana baru pergi ke tempat yang berbeda di luar kebiasaannya. Maka dari itu, konsumen mengalami peningkatan yang cukup signifikan bila dibandingkan dengan bulan lainnya.

Adapun jumlah pelanggan yang paling sedikit berada pada bulan Februari. Pada bulan tersebut pelanggan bus MGI trayek Bandung-Sukabumi berjumlah 155.827 orang. Penyebab terjadi penurunan jumlah penumpang menurut Bapak Ade Suherman, selaku bagian operasional MGI ialah karena bulan Februari merupakan bulan yang tanggal/harinya lebih sedikit dibandingkan dengan bulan lainnya. Bulan Februari hanya memiliki 28 hari, sedangkan Januari memiliki 31 hari. Menurutnya, jumlah hari juga berpengaruh pada pendapatan di tiap bulannya. Namun, hal itu tidak menyurutkan pihak manajemen atau perusahaan untuk tetap melakukan yang terbaik bagi para pelanggannya. Total jumlah pelanggan MGI pada enam bulan tersebut mencapai lebih dari satu juta penumpang. Hal ini menunjukkan bahwa perusahaan MGI terus berusaha untuk meningkatkan citra yang positif dikalangan masyarakat

Konsumen pada dasarnya akan memilih merek yang dinilai memiliki citra positif. Namun pada faktanya, masih terdapat konsumen yang menggunakan produk dari perusahaan yang dinilai memiliki citra negatif atau bahkan tidak tahu sama sekali mengenai kesan yang mereka tangkap dari produk yang akan dibeli atau dipakai. Salah satu penyebabnya yaitu masyarakat Indonesia yang merupakan negara berkembang lebih mengedepankan eksistensi dibandingkan kualitas. Berbeda dengan masyarakat yang tinggal di negara maju lebih mengedepankan fungsional dengan kualitas penduduk yang tinggi.

Hasil wawancara pada tanggal 15 juli 2012 kepada 20 penumpang menemukan bahwa 12 konsumen menyatakan setuju jika merek MGI trayek BandungSukabumi adalah merek bus ternama dan memiliki kualitas yang lebih baik dibandingkan merek bus lain yang dikenalinya. Salah satunya adalah kenyamanan penumpang karena MGI tidak menarik penumpang melebihi batas kapasitas tempat duduk. Sedangkan 5 penumpang tetap menggunakan bus MGI namun menurutnya masih terdapat kekurangan-kekurangan yang harus 
diperbaiki, misalnya kondektur yang kurang ramah. Selain itu, 2 penumpang lainnya tetap menggunakan bus MGI walaupun mereka tidak memprioritaskan keunggulan yang dimiliki oleh MGI. Bus yang akan berangkat itulah yang mereka naiki. Sedangkan 1 orang menyatakan tidak suka menggunakan bus tersebut karena lebih memilih menggunakan bus ekonomi yang bisa lebih leluasa merokok selain harganya yang ekonomis.

Kesan mereka setelah menggunakan produk jasa tersebut, 12 orang menyatakan bahwa mereka merasa bangga menggunakan bus tersebut karena tampak lebih eksklusif dibandingkan dengan bus lainnya. Ketertarikan mereka terhadap MGI juga ditandai dengan kesetiaan menunggu bus karena tidak mau menggunakan bus lain selain bus MGI. Selain itu, harganya terjangkau dan sesuai dengan fasilitas yang ditawarkan. Harga tersebut bersifat tetap dibandingkan dengan perusahaan lain yang selalu melakukan perubahan harga pada momenmomen tertentu terutama hari libur. Mereka juga menyebutkan bahwa MGI tidak menaikkan penumpang jika semua kursi sudah terisi, sehingga para penumpang tidak akan merasakan crowded dibandingkan dengan bus lain yang menampung penumpang melebihi kapasitas yang membuat konsumen tidak merasa nyaman.

Delapan orang lainnya merasakan kurangnya kepuasan terhadap layanan Bus MGI. Hal itu disebabkan oleh beberapa faktor, diantaranya ialah uang kembalian yang lambat diberikan, karcis yang terkadang tidak diberikan, dahulu penumpang dimanjakan dengan minuman gelas gratis tetapi sekarang tidak lagi diberikan, sopir yang selalu ngerem mendadak, serta kondektur yang kurang ramah.

Konsumen yang merasakan adanya ketidak-puasan biasanya akan menceritakan perasaan dan pengalamannya tersebut kepada orang lain. Kotler \&
Amstrong (2001:232) mengemukakan bahwa berdasarkan hasil penelitian menunjukkan bahwa pelanggan menceritakan pengalaman buruk mereka pada empat kali pendengar daripada apabila mereka menceritakan pengalaman yang menyenangkan. Hal itu terbukti melalui sebuah jejaring sosial, peneliti menemukan konsumen yang menyatakan ketidak-puasannya terhadap bus MGI. Pada Blog Afiyah di laman ini http://radarsukabumi.com/?p=3597

ditemukan bahwa rata-rata para sopir bus MGI jurusan Bandung - Sukabumi sering kali mengucapkan kata-kata kasar dan pengendara tidak menggunakan handsfree saat menelfon. Ia juga mengatakan bahwa meski sudah jelas tertera pada stiker bahwa dilarang menggunakan kata-kata kasar dan menggunakan handphone saat mengemudi, tetapi pengendara tidak mengindahkannya. Konsumen yang mengaku sebagai pelanggan setia bus MGI merasa cemas setiap kali naik bus tersebut karena belakangan marak dijumpai kecelakaan lalulintas pada transportasi bus.

Berdasarkan penjelasan pada yang telah dipaparkan sebelumnya, dapat diketahui bahwa konsumen merasa kecewa atas pelayanan yang diberikan oleh bus MGI. Pelanggan yang merasa kecewa merupakan konsumen yang tidak puas akan kinerja yang diberikan oleh perusahaan. Hal tersebut tentunya akan berdampak buruk bagi perusahaan, salah satunya ialah perusahaan akan kehilangan konsumen.

Kehilangan konsumen, memungkinan adanya faktor kepuasan konsumen. Kotler dan Amstrong (2001:9),

Customer Satisfactions is the extent to which a products perceived performance matches a buyer's expectation". If the product's performance falls short of expectation, the buyer is dissatisfied. If performance matches or exceeds expectations, the buyer is satisfied or delighted. 
Jadi, kepuasan konsumen adalah sejauh mana kinerja produk yang diterima memenuhi harapan pembeli. Bila kinerja produk lebih rendah dibandingkan harapan, maka pembelinya akan merasa tidak puas. Bila kinerja produk sesuai atau melebihi harapan, maka pembelinya akan merasa puas atau amat gembira. Secara umum, citra merek yang positif akan didapatkan oleh perusahaan jika perusahaan telah memenuhi kebutuhan para konsumennya, salah satunya adalah kepuasan konsumen. Merek dapat menandakan satu tingkat mutu tertentu, sehingga pembeli yang puas dapat lebih mudah membeli produk (Kotler \&keller, 2009 : 233)

Konsep kepuasan adalah sesuatu yang dinamis, satu waktu konsumen dapat merasa puas, akan tetapi bilamana lingkungannya berubah, kondisinya berbeda (Johannes, 2009: 53). Kepuasan merupakan perasaan senang atau kecewa seseorang yang muncul setelah membandingkan kinerja (hasil) produk yang dipikirkan terhadap kinerja (atau hasil) yang diharapkan (Kotler \& Keller, 2009:17). Konsumen yang merasa puas biasanya akan memuji dan cenderung akan melakukan pembeliang ulang. Sedangkan konsumen yang merasa tidak puas akan berhenti menggunakan produk dan menganggap produk tersebut tidak layak walaupun perusahaan telah melakukan perubahan kepuasan atau rasa senang yang tinggi akan menciptakan ikatan emosional dengan merek atau perusahaan tersebut, bukan hanya sekedar kelebih-sukaan rasional (2009: 179).

Perbedaan-perbedaan

yang ditemukan dari konsumen tersebut menunjukkan, bahwa citra dari merek yang positif tidak selalu menunjukkan pada kepuasan konsumen dan konsumen yang menyatakan ketidak-puasan terhadap perusahaan tidak selalu menunjukkan citra negatif. Buktinya, bus MGI masih diminati oleh konsumen walaupun masih terdapat ketidak-puasan didalam kinerjanya. Kesenjangan yang tampak antara fenomena di lapangan dengan pandangan teori mengenai citra dari sebuah merek dengan kepuasan konsumen membuat penulis merasa tertarik untuk mengetahui bagaimana hubungan antara citra merek dengan kepuasan konsumen, terutama bagi segmentasi pengguna jasa Bus Maya Gapura Intan (MGI) Trayek BandungSukabumi. Oleh karena itu, penelitian ini diangkat dengan judul "Hubungan antara Citra Merek Bus Maya Gapura Intan (MGI) dengan Kepuasan Konsumen pada Trayek Bandung-Sukabumi”.

Berdasarkan latar belakang masalahnya, maka masalah yang akan dianalisa dalam penelitian ini adalah sebagai berikut:

1. Apakah terdapat hubungan positif antara Citra Merek dengan Kepuasan Konsumen Pengguna jasa Bus MGI Trayek Bandung-Sukabumi?

2. Bagaimana Citra Merek pada Konsumen pengguna jasa Bus MGI Trayek Bandung-Sukabumi?

3. Bagaimana Kepuasan Konsumen pengguna jasa Bus MGI Trayek Bandung-Sukabumi?

Adapun tujuan dilakukannya penelitian ini adalah untuk:

a) Mengetahui apakah terdapat hubungan positif antara Citra Merek dan Kepuasan Konsumen pada pengguna Bus MGI Trayek Bandung-Sukabumi;

b) Mengetahui Citra Merek pada konsumen pengguna Bus MGI Trayek Bandung-Sukabumi;

c) Mengetahui Kepuasan Konsumen pada pengguna Bus MGI Trayek Bandung-Sukabumi;

Secara teoritis, hasil penelitian ini diharapkan dapat memberikan manfaat terhadap disiplin ilmu pengetahuan, terutama di bidang Psikologi Konsumen yaitu dalam usahanya memahami perilaku konsumen (consumen behavior) mengenai hubungan antara citra merek dan kepuasan konsumen dengan memberikan bukti empiris mengenai hubungan tersebut. 
Adapun secara praktis, penelitian ini diharapkan dapat berguna bagi pebisnis jasa angkutan bus untuk meningkatkan kualitasnya yaitu dengan melihat keterkaitan antara kepuasan yang didapat oleh konsumen dengan citra mereknya, sehingga menjadi pemicu untuk berupaya melakukan hal-hal yang sesuai dengan harapan target pasar. Misalnya dengan cara membuat kartu member bagi pelanggan yang telah melakukan repetisi pembelian dalam frekuensi tertentu.

Pendekatan penelitian yang digunakan dalam penelitian ini adalah pendekatan kuantitatif, yaitu penelitian yang lebih menekankan pada aspek pengukuran secara objektif, terstruktur, empirik dan terukur. Untuk dapat melakukan pengukuran tersebut, diperlukan pengambilan data berupa sampel dengan menggunakan alat ukur berupa skala, kemudian diolah dalam bentuk angka-angka numerikal dan dianalisis secara kuantitatif dengan menggunakan metode statistik.

Metode penelitian yang digunakan dalam penelitian ini adalah metode korelasional. Metode korelasi digunakan untuk menjelaskan hubungan antara satu variabel dengan variabel lainnya. Menurut Arikunto (2010:313), koefisien korelasi berarti suatu alat statistik yang digunakan untuk membandingkan hasil pengukuran dua veriabel yang berbeda agar dapat menentukan tingkat hubungan antara variabel-variabel ini. Dengan teknik korelasi peneliti dapat mengetahui hubungan variasi dalam sebuah variabel dengan variasi yang lain. (Arikunto, 2007: 247-248). Penelitian ini akan mengukur hubungan dua varibel yang dinamakan dengan metode korelasi bivariat. Koefisien korelasi Bivariat adalah statistik yang dapat digunakan oleh peneliti untuk menerangkan keeratan hubungan antara dua variabel (Arikunto, 2010: 314). Kedua variabel yang akan diukur dinyatakan dengan X1 dan X2. Apabila kenaikan skor pada kedua variabel berjalan searah, maka hubungan seperti itu dinamakan dengan korelasi positif. Sebaliknya, jika skor kedua variabel berlawanan arah yaitu skor pada satu variabel naik dan skor pada variabel lain turun, maka itu disebut dengan korelasi negatif. Kecuali jika nilai kedua variabel tidak terdapat hubungan yang menentu, positif atau negatif, maka variabel-variabel ini dikatakan tidak berkorelasi

Definisi operasional dari citra merek (brand image) adalah asosiasi para penumpang Bus MGI yang kuat terhadap merek dengan mengetahui karakteristik yang ditawarkan merek Bus MGI pada konsumennya. Citra merek ini diukur melalui tinggi rendahnya perolehan skor pada Brand Image Inventory (BII).Kepuasan atau ketidakpuasan pelanggan adalah respon penumpang bus MGI terhadap evaluasi yang dirasakan antara harapan dan kinerja Bus MGI dalam kualitas produk, harga, kualitas pelayanan, dan biaya dan kemudahan untuk mendapatkan jasa Bus MGI. Variabel kepuasan pelanggan diukur dengan menggunakan metode Customer Satisfaction Index (CSI).

Dalam penelitiaan snowball sampling ini mula-mula dipilih salah satu atau dua orang, tetapi karena kedua orang ini belum merasa lengkap terhadap data yang diberikan, maka peneliti mencari orang lain yang dipandang lebih tahu serta dapat melengkapi data yang diberikan oleh dua orang sebelumnya dan begitu seterusnya, sehingga jumlah semakin banyak sampai jumlah sampel terpenuhi.

\section{HASIL PENELITIAN}

\section{Analisis Deskriptif}

Untuk mendeskripsikan citra merek dan kepuasan konsumen pengguna jasa bus Maya Gapura Intan (MGI), peneliti mencari central tendency (seperti mean dan median) dan variability (seperti standar deviasi) untuk menempatkan individu kedalam dua ketegori terpisah, yaitu positif dan negatif. 


\section{a) Citra Merek (Brand Image) Bus Maya Gapura Intan (MGI)}

Berikut adalah hasil analisa skor Brand Image Inventory (BII) pada konsumen yang pernah menggunakan jasa bus MGI Trayek BandungSukabumi.l analisis deskriptif tersebut, $\mathrm{N}$ memperlihatkan jumlah data yang valid, yaitu 350 dan tidak ada data yang hilang (missing) karena angkanya menunjukan nol. Hal tersebut menunjukkan bahwa semua data siap diproses.

Rata-rata perolehan skor pada Brand Image Inventory (BII) yakni sebesar 130.91 (dibulatkan menjadi 131) dengan Standard error of mean sebesar 0.976. Standard error of mean ini digunakan untuk memprediksi rata-rata populasi dari sampel. Dalam penelitian ini, peneliti menggunakan tingkat kepercayaan 95 persen, oleh karena rata-rata populasi menjadi:

$$
\begin{aligned}
\text { Rata-rata Populasi } & =\text { mean } \pm 2 \text { standard error of mean } \\
= & 130.91 \pm(2 \times 0.976) \\
= & (130.91-1.952) \text { sampai }(130.91+ \\
& 1.952) \\
= & 128.958 \text { sampai } 132.862
\end{aligned}
$$

Selanjutnya, diperlukan standard deviations untuk dapat menentukan besar rata-rata sampel.

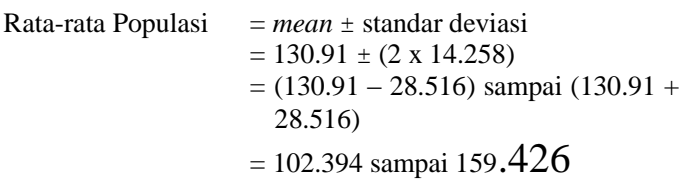

Berdasarkan hasil perhitungan tersebut dapat diketahui bahwa nilai rata-rata sampel dan rata-rata populasi memiliki nilai yang tidak berbeda jauh dengan selisih 26.56 angka.

Median atau titik tengah merupakan data yang disusun atau diurutkan menurut nilainya kemudian dipilih nilai yang berada paling tengah. Pengukuran ini bertujuan untuk menentukan kategorisasi konsumen pengguna bus Maya Gapura Intan (MGI)
Trayek Bandung-Sukabumi. Berdasarkan hasil SPSS diatas, dapat diketahui nilai median sebesar 131.38. Hal itu berarti bahwa konsumen yang memiliki skor > 131.38 termasuk kategori citra positif sedangkan konsumen yang memiliki skor $\leq 131.38$ termasuk kategori citra negatif

Range merupakan rentang antara data maksimum dengan data minimum. Skor range dalam penelitian ini ialah sebesar 126. Skor minimum sebesar 57 sedangkan skor maksimumnya sebesar 183. Adapun angka persentil menunjukkan bahwa:

1) Rata-rata citra merek 10 persen subjek berada dibawah 106,20.

2) Rata-rata citra merek 25 persen subjek berada dibawah 118,86.

3) Rata-rata citra merek 50 persen subjek berada dibawah 131,38.

4) Rata-rata citra merek 75 persen subjek berada dibawah 142,72.

5) Rata-rata citra merek 90 persen subjek berada dibawah 152,00.

b) Kepuasan Konsumen (Customer Satisfaction) Trayek BandungSukabumi

Berikut merupakan hasil analisa skor Costumer Satisfaction Index (CSI) pada konsumen pengguna jasa bus Maya Gapura Intan (MGI) Trayek Bandung-Sukabumi.

Hasil analisis deskriptif tersebut, terdapat 350 jumlah data yang valid dan tidak terdapat data yang hilang karena skornya nol. Hal tersebut menunjukkan bahwa semua data siap untuk diproses. Nilai Mean sebesar 132.84 dengan Standard Error of Mean sebesar 0.923 akan didapat rata-rata populasi yang diprediksikan dari sampel sebagai berikut:

\footnotetext{
Rata-rata Populasi $=$ mean \pm 2 standard error of mean $=132.84 \pm(2 \times 0.923)$

$=(132.84-1.846)$ sampai $(132.84+$ 1.846)

$=130.994$ sampai 134.686

Rata-rata Sampel $=$ mean \pm 2 standard deviation $=132.84 \pm(2 \times 17.275)$
} 
$=(132.84-34.55)$ sampai $(132.84+$ 34.55)

$=98.29$ sampai 167.39

Hasil perhitungan tersebut menunjukkan bahwa rata-rata sampel dan rata-rata populasi memiliki nilai yang tidak jauh berbeda dengan selisih sebesar 32.704 .

Untuk menentukan kategorisari apakah termasuk kedalam kategori puas atau tidak puas digunakan skor titik tengah (median). Skor median dalam penelitian ini yaitu 132.00, hal itu berarti bahwa konsumen yang memiliki skor > 132.00 termasuk kedalam kategori puas sedangkan konsumen yang memiliki skor $\leq 132.00$ termasuk kategori tidak puas.

Nilai maksimum dalam data penelitian ini sebesar 185 sedangkan nilai minimumnya yaitu 64 dengan range sebesar 121. Adapun makna angka persentil dalam penelitian ini ialah sebagai berikut:

1) Rata-rata kepuasan konsumen 10 persen subjek berada dibawah 110,00.

2) Rata-rata kepuasan konsumen 25 persen subjek berada dibawah 120,00 .

3) Rata-rata kepuasan konsumen 50 persen subjek berada dibawah 132,00 .

4) Rata-rata kepuasan konsumen 75 persen subjek berada dibawah 145,00.

5) Rata-rata kepuasan konsumen 90 persen subjek berada dibawah 153,90 .

\section{Analisis Inferensial}

Dalam penelitian ini, peneliti menggunakan formula Product-Moment Pearson. Untuk dapat menggunakan formula ini, salah satunya ialah kedua variabel harus linier. Agar linieritas hubungan dapat dipenuhi, maka data yang digunakan harus mempunyai distribusi normal. Data yang mempunyai distribusi normal ialah data yang distribusinya simetris sempurna (Sarwono, 2009: 58). Analisis mean dan standar deviasi dapat juga digunakan untuk melihat apakah data tersebut berdistribusi normal atau tidak dengan melihat histogram dan kurva normalnya

Dari gambar, terlihat bahwa batang histogram lebih banyak berkumpul di tengah dibanding di sisi kanan atau kiri. Jika melihat bagaimana bentuk kurva normal, maka suatu data dapat dikatakan berdistribusi normal ketika data tersebut lebih banyak berkumpul di tengah, oleh karena itu sebaran data citra merek dan kepuasan konsumen dapat dikatakan berdistribusi normal.

Setelah diketahui bahwa kedua data tersebut memiliki distribusi normal, maka uji linieritas pun dapat dilakukan.

Data dapat dikatakan linear apabila $\alpha$ $\leq$ Sig. hasil pengolahan SPSS, sebaliknya data disebut tidak linear jika $\alpha \geq$ Sig. hasil pengolahan SPSS. Dalam penelitian ini, taraf signifikansi yang digunakan oleh peneliti sebesar $95 \%$ atau $\alpha=0.05$. Berdasarkan hasil pengolahan tersebut, dapat diketahui bahwa $\alpha<$ Sig. $(\alpha 0.05<$ Sig. 0.151), sehingga dapat disimpulkan bahwa citra merek memiliki hubungan yang sejajar atau simetris dengan kepuasan konsumen.

Bukti-bukti seperti histogram dengan kurva yang normal serta variabel yang linier telah menunjukkan bahwa data tersebut berdistribusi normal dan terbukti linear sehingga telah memenuhi syarat untuk agar peneliti dapat menggunakan Product Moment Pearson untuk menganalisis korelasi antara citra merek dan kepuasan konsumen.

Berdasarkan analisis Product Moment Pearson, citra merek dan kepuasan konsumen pada pengguna jasa Bus Maya Gapura Intan (MGI) Trayek Bandung-Sukabumi memiliki nilai koefisien sebesar 0.684. berdasarkan klasifikasi Bungin (2011:194), maka koefisien ini termasuk kedalam kategori hubungan positif yang mantap. Untuk lebih 
menguatkan penelitian, maka setiap dimensi citra merek dan kepuasan konsumen juga menunjukkan korelasi yang positif

Hasil bahwa terdapat 3 domain citra merek (jenis asosiasi merek, dukungan asosiasi merek, dan kekuatan asosiasi merek) memiliki korelasi positif yang mantap dengan dimensi kepuasan konsumen pada domain product quality. Konsumen merasa puas terhadap kualitas produk yaitu konsumen yang menganggap bahwa functional value yang dijanjikan perusahaan sesuai dengan harapan, waktu keberangkatan sudah terbilang cepat, AC masih berfungsi secara baik, fassilitas yang diberikan sudah cukup sesuai, merasa bangga terhadap kualitas yang diberikan oleh bus MGI trayek Bandung-Sukabumi.

Adapun untuk dimensi citra merek yang positif pada domain jenis asosiasi merek adalah konsumen yang merasa bahwa atribut-atribut yang ada pada bus MGI seperti nama, logo, produk, harga, label, iklan dan distribusi serta manfaat dari penggunaan bus MGI sudah seusai dengan harapan konsumen. Pada domain dukungan asosiasi merek juga memiliki korelasi positif yang mantap terhadap kualitas produk. Hal itu berarti bahwa kualitas produk yang sudah sesuai dengan harapan konsumen telah memunculkan adanya keinginan konsumen terhadap merek serta menyatakan sikap yang mendukung terhadap merek, yaitu dengan rela menunggu dan mengabaikan bus yang ada hanya untuk menggunakan bus MGI trayek Bandung-Sukabumi. Demikian juga dengan domain kekuatan asosiasi merek yang menganggap bahwa kualitas produk sudah sesuai dengan harapan konsumen sehingga memunculkan keyakinan terhadap merek. Konsumen merasa yakin jika merek bus MGI memiliki kualitas yang lebih baik dibandingkan dengan bus pada trayek Bandung-Sukabumi lainnya. Sedangkan satu dimensi yaitu keunikan asosiasi merek hanya memiliki korelasi yang sedang dengan kualitas produk. Hal itu menunjukkan bahwa produk yang dimiliki bus MGI cukup dapat dibedakan dengan merek pesaing.

Untuk dimensi price terdapat satu dimensi citra merek dengan korelasi positif yang mantap, yaitu jenis asosiasi merek yang meunjukkan bahwa tarif bus MGI masih dapat dijangkau oleh konsumen . Sedangkan tiga lainnya memiliki korelasi positif yang sedang, yakni dukungan, kekuatan dan keunikan asosiasi merek yang berarti bahwa kesesuian harga yang dirasakan oleh konsumen membuat konsumen melakukan pembelian ulang.

Untuk dimensi service quality, terdapat dua dimensi citra merek dengan korelasi positif yang mantap, yakni jenis serta kekuatan asosiasi merek yang menunjukkan bahwa konsumen merasakan kepuasan terhadap kualitas pelayanan bus MGI sehingga memunculkan citra yang baik terhadap atribut merek serta merasakan manfaat dari merek. Konsumen merasa yakin jika merek memiliki kualitas yang baik. Dua dimensi lainnya berkorelasi positif sedang, yaitu dukungan serta keunikan. Konsumen merasakan kualitas pelayanan yang diberikan bus MGI sudah sesuai dengan harapan namun keunikan yang dimiliki terkesan standar sehingga dukungan terhadap merek terkesan biasa saja.

Pada dimensi emotional factor, terdapat tiga citra merek dengan korelasi positif yang mantap yaitu jenis, dukungan dan kekuatan yang berarti bahwa self esteem dan social value konsumen yang positif terhasap bus MGI trayek BandungSukabumi memunculkan sikap konsumen yang loyal dan ingin menggunakan bus MGI dikemudian hari. Satu citra merek dengan korelasi positif yang sedang yaitu keunikan menunjukkan bahwa merek bus MGI cukup dapat dibedakan dengan merek pesaing tetapi belum mampu menunjukkan keunikan yang sangat khas.

Sedangkan untuk dimensi cost of acquiring, tiga dimensi citra merek memiliki korelasi positif yang sedang 
sedangkan satu dimensi memiliki korelasi positif yang tak berarti. Kemudahan dalam bertransaksi serta kemudahan memperoleh bus masih terbilang standar. Artinya, transaksi dilakukan dengan cara petugas menagih uang kepada konsumen dari seat satu ke seat lainnya sama seperti yang dilakukan oleh petugas bus pada umumnya. Kemudahan memperoleh bus juga akan tergantung pada posisi dimana konsumen akan menaiki bus. Bus MGI Trayek Bandung-Sukabumi salah satunya berada diterminal Leuwipanjang begitu pula dengan bus yang lain pada trayek yang sama. Jadi, domain cost of acquiring pada bus MGI trayek Bandung-Sukabumi tidak jauh berbeda dengan pelayanan pada bus umumnya.

\section{PEMBAHASAN}

Berdasarkan hasil penelitian terhadap 350 konsumen pengguna jasa bus Maya Gapura Intan (MGI) Trayek BandungSukabumi, sebesar 53.71 persen memiliki citra merek yang positif, sedangkan 46.29 persen lainnya memiliki citra merek yang negatif. Hasil menunjukkan bahwa tingkatan antara citra merek yang positif dengan citra merek yang negatif hampir tidak memiliki perbedaan yang signifikan, yakni hanya berselisih 7.42 persen. Hal itu menunjukkan bahwa jumlah konsumen yang memiliki citra merek positf tidak jauh berbeda dengan jumlah konsumen yang memiliki citra negatif meskipun jumlah citra yang positif lebih banyak dibandingkan dengan citra yang negatif.

Ketika konsumen menggunakan merek tertentu maka akan terjadi pola hubungan antara konsumen dengan merek. Hubungan tersebut yang menjadi penentu apakah mengandung kesan positif atau negatif. Citra yang buruk menimbulkan persepsi produk tidak berkualitas, sehingga pelanggan mudah marah untuk kesalahan kecil sekalipun. Citra yang baik menimbulkan persepsi produk berkualitas, sehingga pelanggan memaafkan suatu kesalahan, meskipun tidak untuk kesalahan selanjutnya (Freddy Rangkuti, 2006:34).

Dalam penelitian ini, konsumen yang memiliki citra merek yang positif ialah mereka yang senantiasa menggunakan merek bus MGI dan merasa yakin akan kualitasnya sehingga memunculkan preferensi terhadap merek. Jika konsumen telah memperlihatkan preferensi terhadap merek, maka konsumen akan cenderung melakukan repetisi pembelian sehingga dengan intensitas penggunaan bus MGI yang sering, konsumen dapat dengan mudah mengetahui atribut-atribut yang ada didalam merek bus MGI. Ferrinadewi (2008: 142) mengatakan bahwa Konsumen akan terus berharap pada merek untuk menyediakan pengalaman menyenangkan yang melibatkan mereka.

Dengan kata lain, konsumen dengan citra merek yang positif adalah konusmen yang merasakan adanya ekslusivitas yang ditawarkan dari sebuah merek, salah satunya ialah pengalaman menyenangkan yang didapat dari penggunaan merek bus MGI Trayek Bandung-Sukabumi. Konsumen akan mengetahui bahwa pengalamannya menyenangkan jika telah menggunakan merek yang dirasa biasa saja bahkan tidak menyenangkan. Dengan begitu, konsumen akan menyadari bahwa merek bus MGI memiliki keunikan tersendiri dibandingkan dengan merek lainnya bahkan menganggap bahwa bus MGI Trayek Bandung-Sukabumi adalah merek bus yang berkualitas dibandingkan dengan merek bus lainnya.

Senada dengan penelitian Poiezs (dalam Ferrinadewi, 2008:3) yang menyatakan bahwa konsumen lebih menekankan pada aspek-aspek afektif dan hedonis, akibatnya sering terjadi kosumen yang melakukan pembelian bukan karena kebutuhan namun karena emosi. Penelitian ini mengungkapkan bahwa citra merek positif sedikit lebih besar dibandingkan dengan citra merek negatif. Hal itu berarti bahwa konsumen cenderung memilih bus Maya Gapura Intan (MGI) Trayek 
Bandung-Sukabumi ialah karena kebanyakan orang juga menggunakan bus tersebut sehingga terdapat kemungkinan jika konsumen menggunakan bus lain, ia akan terlihat berbeda. Selain itu, bus MGI yang terkesan ekslusif dibandingkan bus lainnya menjadikan alasan bagi konsumen untuk memilih bus tersebut tanpa mempertimbangkan kenyamanan dan kebutuhan.

Adapun citra merek yang negatif terbentuk dari konsumen yang tidak selektif dalam memilih merek, sehingga tidak terjadi proses preferensi terhadap merek. Konsumen yang memiliki citra negatif adalah mereka yang tidak memprioritaskan keunggulan merek. Bus yang lebih dulu ada, itulah yang mereka pilih. Kebanyakan dari mereka lebih memilih bus yang akan lebih dahulu berangkat dibandingkan keunggulan mereknya. Oleh karena itu, konsumen tidak begitu menyadari atribut-atribut yang ada didalam merek bus Maya Gapura Intan (MGI) karena merasa bahwa bus yang mereka gunakan terlihat standar dan terkesan biasa-biasa saja. Selain itu, konsumen menganggap bahwa merek tersebut tidak memiliki kualitas yang lebih baik dibandingkan dengan bus lainnya ditambah lagi informasi yang mereka dapatkan mengenai bus MGI berbeda-beda sehingga konsumen mengalami kebingungan dalam mempersepsi kualitas bus yang digunakan.

Berbeda dengan hasil analisis variabel citra merek yang jumlah positifnya lebih banyak, variabel kepuasan konsumen memiliki jumlah kepuasan yang sedikit lebih rendah dibandingkan dengan konsumen yang tidak puas. Berdasarkan hasil penelitian didapatkan 50.30 persen konsumen menyatakan tidak puas dan sisanya 49.70 menyatakan puas terhadap pelayanan bus MGI Trayek BandungSukabumi.

Hasil penelitian yang dilakukan oleh Oliver (dalam Ferrinadewi, 2008: 2) menyatakan bahwa kepuasan konsumen merupakan sebuah konsep yang didasarkan dari perasaan manusia. Ketika seseorang merasa puas hal ini menunjukkan kinerja produk mampu memenuhi keinginan konsumen. Pelanggan yang puas akan kembali membeli produk, memuji produk yang dibelinya dihadapan orang lain, sedikit menaruh perhatian pada merek dan iklan pesaing, dan membeli produk lain dari perusahaan yang sama. (Kotler \& Amstrong, 2001: 228).

Konsumen yang puas terhadap kinerja Bus MGI Trayek BandungSukabumi adalah mereka yang kembali lagi menggunakan jasa bus MGI bahkan sebagian dari mereka telah berniat akan menggunakan bus MGI tersebut saat hendak bepergian ke daerah sekitar Bandung-Sukabumi. Konsumen bahkan rela menunggu lama dan mengabaikan bus yang ada hanya untuk menggunakan bus MGI karena mereka percaya akan kualitas, keamanan serta kenyamanan yang dimiliki oleh bus MGI. Selain itu juga terdapat konsumen yang menganjurkan oranglain untuk menggunakan bus MGI tersebut, seperti yang juga dikemukakan oleh Kotler \& Amstrong (2001: 227) yang menyatakan bahwa pelanggan senang sekali dengan kinerja yang melebihi harapan; mereka membeli lagi dan menceritakan pada pelanggan potensial lain. Disamping itu,terdapat konsumen yang menyarankan agar armada bus MGI diperbanyak jumlahnya karena jumlah konsumen yang semakin meningkat.

Kotler \& Amstrong (2001: 228) menyatakan pendapat lain, bahwa konsumen yang tidak puas merespon dengan sangat berbeda. Kalau rata-rata pelanggan yang puas menceritakan pada 3 orang lainnya mengenai pengalaman mereka atas produk yang baik, seorang pelanggan yang tidak puas akan mengeluh pada 11 orang. Kenyataannya, suatu penelitian menunjukkan bahwa 13 persen orang yang memiliki masalah dengan suatu perusahaan mengeluhkan perusahaan tersebut pada lebih dari 20 orang. Jelas, 
berita jelek lebih luas dan lebih cepat menyebarnya dari pada berita baik, dan dapat dengan cepat merusak sikap konsumen mengenai perusahaan dan produk-produknya. Pelanggan yang menceritakan ketidakpuasannya terhadap suatu produk lebih banyak daripada pelanggan yang menceritakan kepuasannya. Maka dari itu, pelanggan yang tidak puas tidak hanya berhenti membeli tetapi juga dengan cepat dapat membahayakan citra perusahaan (Kotler \& Amstrong, 2001: 232).

Apabila mengacu kepada hal tersebut, maka konsumen yang menyatakan tidak puas ialah mereka yang menceritakan pengalaman buruknya kepada oranglain dan berhenti menggunakan produk serta menganggap produk tersebut tidak layak walaupun perusahaan telah melakukan perbaikan atas kinerjanya. Menurut Kotler \& Keller (2009: 180) mengatakan bahwa internet menyediakan alat bagi para konsumen untuk menyebrkan cerita buruk dan juga cerita baik kepada orang lain di dunia. Hal tersebut diperkuat dengan temuan data awal peneliti yang menemukan bahwa terdapat konsumen yang menceritakan pengalaman buruknya melalui sebuah jejaring sosial, yaitu blog. Isi blog tersebut menceritakan bahwa terdapat beberapa sopir bus MGI jurusan Bandung - Sukabumi yang sering kali mengucapkan kata-kata kasar dan sopir menelfon saat mengendarai bus. Ia juga mengatakan bahwa meski sudah jelas tertera pada stiker bahwa dilarang menggunakan kata-kata kasar dan menggunakan handphone saat mengemudi, tetapi sopir tersebut mengabaikannya. Konsumen yang mengaku sebagai pelanggan setia bus MGI merasa cemas setiap kali naik bus tersebut karena belakangan marak dijumpai kecelakaan lalulintas pada transportasi bus.

Oleh karena itu, jelas terdapat korelasi yang mantap antara citra merek bus Maya Gapura Intan dengan kepuasan konsumen pada trayek Bandung-Sukabumi, sehingga diharapkan perusahaan selalu mengusahakan untuk memelihara bahkan mengembangkan pelayanan ke arah yang lebih baik lagi agar dapat meningkatkan kepuasan konsumen atau pelanggannya.

\section{SIMPULAN}

Berdasarkan hasil pengolahan data dan pengujian hipotesis mengenai hubungan antara citra merek bus Maya Gapura Intan (MGI) dengan kepuasan konsumen pada trayek Bandung-Sukabumi, peneliti memberi kesimpulan sebagai berikut:

1. Terdapat Korelasi yang mantap antara citra merek dengan kepuasan konsumen. Hal itu berarti bahwa semakin tinggi citra merek yang positif terhadap bus Maya Gapura Intan, akan semakin besar pula tingkat kepuasan konsumennya. Taraf korelasi positif yang mantap yakni sebesar 0.684 .

2. Sebesar 53.71 persen memiliki citra merek yang positif, sedangkan 46.29 persen lainnya memiliki citra merek yang negatif. Konsumen yang memiliki citra positif adalah konsumen yang menyadari akan adanya atribut-atribut dalam merek, merasa bahwa merek tersebut berkualitas serta merasakan adanya keunikan dari merek bus MGI. Sebaliknya, konsumen yang memiliki citra negatif ialah konsumen yang tidak menyadari atribut-atribut merek, merasa bahwa merek tidak berkualitas, tidak mengetahui ataupun merasakan adanya keunikan merek bus MGI atau mengalami kebingungan karena informasi yang diberikan petugas tidak seragam sehingga membuat konsumen mempersepsikan produk berbeda-beda.

3. Didapatkan 50.30 persen konsumen menyatakan tidak puas dan sisanya 49.70 menyatakan puas terhadap pelayanan bus MGI pada trayek Bandung-Sukabumi. Hal ini menunjukkan bahwa terdapat sejumlah konsumen yang cenderung tidak loyal terhadap bus MGI. Konsumen memilih 
menggunakan bus mana saja tanpa mengutamakan bus MGI. Meskipun demikian, masih terdapat pula konsumen yang loyal terhadap bus MGI dengan rela menunggu dan mengabaikan bus yang ada hanya untuk menggunakan bus MGI.

\section{SARAN}

Mengingat segala keterbatasan dalam penelitian ini maka penelitian mengusulkan saran akademik dalam rangka mewujudkan aplikasi psikologi indusri dan organisasi khususnya psikologi konsumen dan psikologi pemasaran serta saran aplikatif yang diharapkan dapat dijadikan bahan pertimbangan bagi pihakpihak yang mempunyai peranan penting serta pengaruh yang cukup besar terhadap pengambilan keputusan dalam mengaplikasikan konsep psikologi konsumen ini. Adapun saran akademik dan aplikatifnya ialah sebagai berikut:

1. Saran Akademik

a) Penelitian ini terbatas pada pengukuran kualitas citra merek dan kepuasan konsumen, yakni hanya dapat mendeskripsikan tingkatan tinggi dan rendah saja sehingga untuk hasil jumlah yang hampir sama besarnya kurang dapat mencakupi kategori mana yang dominan karena perbedaan selisih yang kecil. Disamping itu, domain dari masingmasing karakteristik positif-negatif masih terbatas. Penelitian selanjutnya diharapkan dapat mengkaji lebih dalam mengenai faktor-faktor yang mempengaruhi proses pembentukan citra merek seseorang serta indikator apa saja yang mencakup kepuasan konsumen dengan melakukan tingkatan analisis yang lebih tinggi.

b) Jumlah populasi pada pengguna bus MGI yang terhitung banyak, membuat peneliti sulit menentukan ukuran jumlah sampel, sehingga untuk penelitian selanjutnya diharapkan dapat mengerucutkan penelitian menjadi sesuatu yang lebih spesifik lagi sehingga memudahkan peneliti dalam pengambilan sampelnya.

2. Saran Aplikatif

Mengingat belakangan ini kecelakaan lalulintas khususnya kendaraan transportasi bus marak terjadi, sebagai pihak penyedia jasa yang bergerak dalam bidang transportasi, PT. Maya Gapura Intan (MGI) diharapkan mampu meningkatkan keamanan, kenyamanan serta keselamatan penumpang dengan cara melalukan pre-control pada setiap armada bus minimal satu jam sebelum keberangkatan serta melakukan kontrol secara berkala minimal tiga bulan sekali. Selain itu juga diharapkan kepada petugas, baik sopir maupun kondektur agar dapat menjaga kesehatan fisik serta kesehatan psikologis sehingga bisa dipastikan sopir dan kondektur siap bekerja melayani konsumen dalam hal ini penumpang bus MGI. Misalnya dengan melakukan tes urin, terutama menjelang Bulan Ramadhan dan Hari Raya sehingga bisa dipastikan bahwa petugas MGI bebas dari penggunaan alkohol dan obat-obatan.

PT. Maya Gapura Intan (MGI) yang disebut sebagai penyedia jasa transportasi darat, diharapkan mampu meningkatkan aktivitas pemasaran yang sesuai dengan target branding serta menentukan product positioning yang lebih optimal. Misalnya dengan menciptakan kartu member bagi para pelanggannya dengan keuntungan diskon 5 atau $10 \%$ bagi yang memiliki member, memberikan reward berupa bingkasan atau merchandise berlabel MGI seperti kaos, payung, dan lain-lain bagi penumpang yang telah menggunakan bus MGI. Selain itu, pihak MGI diharapkan melakukan pemasaran pada jejaring sosial mengingat jejaring sosial merupakan salah satu pemasaran yang paling efektif di era modern ini. Hal itu sangat penting untuk 
membuat merek yang lebih dikenal luas dan memberikan citra yang benar-benar sesuai dengan yang diinginkan oleh perusahaan.

\section{DAFTAR PUSTAKA}

Alfiyah, Viny. (2012). Sopir Bus MGI Mengecewakan. (online). Tersedia: http://radarsukabumi.com/?p=3597 (diakses 18 Maret 2013).

Alma, Buchari. (2011). Manajemen Pemasaran dan Pemasaran Jasa. Bandung: Alfabeta.

Andreas. (2011). (online). Tersedia: http://andreas23.multiply.com/photos /photo/39/5 (diakses 16 Juli 2012).

Arikunto, Suharsimi. (2010). Prodesur Penelitian (Suatu Pendekatan Praktik). Jakarta: Rineka Cipta. (2007). Manajemen Penelitian. Jakarta: Rineka Cipta.

Atkinson, dkk. (n.d). Pengantar Psikologi Edisi Kesebelas Jilid 1. Batam: Harcourt Brace \& Company.

Azwar, Saifudin. (2010). Sikap Manusia. Yogyakarta: Pustaka Pelajar.

Bungin, Burhan. (2011). Metodologi Penelitian Kuantitatif: Kumunikasi, Ekonomi, dan Kebijakan Publik Serta Ilmu-Ilmu Sosial Lainnya. Jakarta: Kencana.

Champion, Dean J. 1981. Basic Statistics for Social Research. Second Edition. New York: Macmillan Publishing Co. Inc.

Departemen Agama RI. (2005). Al-Quran dan Terjemahnya Special for Women. Bandung: SYGMA.

Ferdinand, A. T. (1999). "Strategic Patways Toward Sustainable Competitive Advantage". Unpublished DBA Thesis, Soutern Cross, Lismore, Australia.

Ferrinadewi, Erna. (2008). Merek dan Psikologi Konsumen. Yogyakarta: Graha Ilmu.

Fitriana, Rahmani. (2011). About Bus.(online). Tersedia: http://rahmanifitriana.blogspot.com/2 011/04/talk-bout-bus.html (diakses 16 Juli 2012).

Friedenberg, Lisa. (1995). Psychological Testing: Design, Analysis and Use. The University of North Carolina at Asheville.

Hasson, Bruno. (2008). Fashion Branding (Tujuh jurus sukses Branding Bisnis MLM Fashion). Jakarta: PT.Gramedia Pustaka.

Irawan, Handi. (2003). Indonesian Customer Satisfaction (Membedah Strategi Kepuasan Pelanggan Merek Pemenang ICSA). Jakarta: PT. Elex Media Komputindo.

Jamieson, Susan. (2004). Medical Education. Blackwell Publishing Ltd.

Johannes. (2009). Kepuasan Pelanggan: Riviu dan Pengembangannya dalam Melakukan Penelitian. Jurnal Manajemen Pemasaran Modern, Vol.1 No.1, hal.53.

Kotler, Philip. (2000). Marketing Management, The Millennium Edition, New Jersey: Prentice- Hall International, Inc.

$$
\text { (2002). Manajemen }
$$

$$
\text { Pemasaran. Jakarta: PT. }
$$

Prenhallindo.

Kotler, Philip and Gary Amstrong.(2008). Principles of Marketing. Unites States of America : Prentice Hall.

(2001). Prinsip-Prinsip Pemasaran Jilid 1 Edisi Kedelapan. Jakarta: Erlangga.

Kotler, Philip \& Keller (2009). Manajemen Pemasasaran Edisi Keduabelas Jilid 1. Indonesia: Indeks.

Norman, Geoff (2008). Likert Scales, Levels of Measurement and "The Laws" of Statistic. Canada: Mc. Master University, 1200 Main St. W., Hamilton, ON L8N3Z5.

Pamungkas \& Diah. (2010). Evaluasi Tarif Angkutan Umum Penumpang Kota Semarang (Studi Kasus Bus Patas AC Rute Banyumanik - Pasar Johar 
dan Pucang Gading-Ngaliyan). (online). Tersedia: http://eprints.undip.ac.id/34582/5/20 98_chapter_II.pdf (diakses 3 Mei 2013)

Purnomo, Dony. (2012). Unsur-Unsur Dasar Transportasi.(online). Tersedia:

http://pinterdw.blogspot.com/.../unsu r-unsur-dasar--transportasi.html (diakses 19 Juli 2012).

Rangkuti, Freddy. (2007). Riset Pemasaran. Jakarta: PT. Gramedia Pustaka Utama.

Sambe, Nur Jannah. (2012). Hubungan Antara Citra Merek Sophie Paris dengan Konsep Diri Siswi Kelas XI dan XII Madrah Aliyah Negeri (MAN) 1 Kota Bandung. Skripsi Psikologi UIN SGD Bandung ( Juli 2012).

Sarwono, Jonathan (2009). Statistik Itu Mudah: Panduan Lengkap Untuk Belajar Komputasi Statistik Menggunakan SPSS 16. Yogyakarta: ANDI.
Sudjana. (2005). Metoda Statistik. Bandung: Tarsito.

Shimp, Terence A. (2003). Periklanan Promosi Aspek Tambahan Komunikasi Terpadu. Jakarta: Erlangga.

Simamora, Bilson. (2008). Panduan Riset Perilaku Konsumen. Jakarta: Gramedia Pustaka Utama.

Sugiyono. (2012). Metode Penelitian Kuantitatif Kualitatif dan $R \& D$. Bandung: Alfabeta.

Supranto (2006). PENGUKURAN TINGKAT KEPUASAN PELANGGAN Untuk Menaikkan Pangsa Pasar. Jakarta: Rineka Cipta.

Sutisna. (2002). Perilaku Konsumen dan Komunikasi Pemasaran. Bandung: Rosda.

Tjiptono, Fandy \& Chandra, G. (2011). Service, Quality, \& Satisfaction Edisi: 3. Yogyakarta: ANDI.

Umar, Husein. (2005). Riset Pemasaran dan Perilaku Konsumen. Jakarta: PT. Gramedia Pustaka Utama. 